This is a pre-copyedited, author-produced PDF of an article accepted for publication in the International Journal of Constitutional Law following peer review.

\title{
Constitutional Review of Treaties: Lessons for Comparative Constitutional Design and Practice
}

\section{Introduction}

The relationship between the national constitution and international law was rightly referred to a decade ago as one of the most pressing questions of contemporary constitutional law, ${ }^{1}$ and yet it remains an area in which there has been relatively little recent comparative scholarship. ${ }^{2}$ Certainly as concerns the focus of this paper, constitutional review of treaties, scholarship with a comparative bent has remained in particularly short supply and is even close to non-existent in the English language. ${ }^{3}$ Indeed one of the few explicitly comparative contributions in English continues to be the analysis provided in a 1971 monograph of one dimension of constitutional review of treaties - the ex post variety - in a handful of constitutional systems. ${ }^{4} \mathrm{~A}$ monograph in German was recently published which explores constitutional review of treaties in Brazil in a comparative European perspective. ${ }^{5}$ There is also a valuable recent monograph in French on the ex ante constitutional review of treaties in one constitutional system - the EU - which offers some engagement with ex post treaty

\footnotetext{
${ }^{1}$ See Mattias Kumm, Constitutional Law Encounters International Law: Terms of Engagement in THE Migration Of CONSTitutional IDEAS 256, 256-257 (Sujit Choudhry ed., 2006).

${ }^{2}$ Indeed only one of the three recent research handbooks on comparative constitutional law has a specific chapter engaging with the relationship between international law and constitutional law: see Anne Peters \& Ulrich Preuss, International Relations and International Law, in RouTLEDGE HANDBOOK OF CONSTitutional LAW (Mark Tushnet, Thomas Fleiner \& Cheryl Saunders eds., 2013). The other handbooks are THE OXFORD HANDBOOK OF COMPARATIVE CONSTITUTIONAL LAW (Michel Rosenfeld \& András Sajó eds., 2013) and Comparative Constitutional LaW (Tom Ginsburg \& Rosalind Dixon eds., 2011).

${ }^{3}$ A political scientist has recently provided valuable comparative analysis of constitutional review of EU treaties by national courts: Carlos Closa, National Higher Courts and the Ratification of EU Treaties, 36 West EUR. POL. 97 (2013).

${ }^{4}$ See LuZius Wildhaber, TREATY-MAKing POWER AND CONSTitution - AN INTERNATIONAL AND COMPARATIVE StUdy, Pt III (1971).

${ }^{5}$ Eleonora Mesquita Ceia, Die Verfassungsgerichtliche Kontrolle Völkerrechtlicher VERTRÄGE - EINE RECHTSVERGLEICHENDE UNTERSUCHUNG ZWISCHEN BRASILIEN UND EUROPA [Constitutional Court ReView of International Treaties: A Comparative Study of BraziL AND EUROPE] (2011).
} 
review in that system and makes some use of comparative examples. ${ }^{6}$ But recent work on, for example, constitutional courts has tended to leave aside or, at best, give only passing mention to this dimension of their jurisdiction. ${ }^{7}$ This is also so for a well-known article on "ancillary powers" of constitutional courts which identified this as the second most common ancillary power. ${ }^{8}$ And even where one would expect significant attention accorded to constitutional review of treaties, such as recent edited collections on international law - and even treaties specifically - and domestic legal systems, it has been lacking and is thus further evidence of the relative neglect of this terrain. ${ }^{9}$

Despite this neglect, it is terrain that brings to the fore important issues of constitutional design and practice concerning the relationship between domestic constitutional law and international law and would benefit greatly from more sustained comparative treatment. This article attempts to offer this more sustained comparative treatment while arguing that a powerful case can be made for constitutional systems to adopt both ex ante and ex post constitutional review of treaties. To this end, this article is divided into two core sections. A first section focuses on quantitative and qualitative transformations that have been taking place in relation to treaty-making, and on identifying some core domestic constitutional transformations in relation to the treaty-making power. This section seeks to place the emergence of constitutional review of treaties in its appropriate context, namely as one of a range of domestic constitutional transformations that have emerged primarily because of increased recognition of the transformed terrain of, and constitutional

\footnotetext{
${ }^{6}$ Stanislas adam, La Procedure D'avis devant la Cour De Justice De L'union Europeenne [The Opinion Procedure Before The Court Of Justice of The European Union] (2011).

${ }^{7}$ Examples include Wojciech SAdurski, Rights Before Courts: A StUdy Of Constitutional Courts In Post-Communist States of Central And EASTERn Europe (2014); Allan BrewerCARias, Constitutional Courts As Positive Legislators - A Comparative LaW Study (2011); Constitutional Courts - A Comparative Study (Andrew Harding \& Peter Leyland eds., 2009); For greater attention to this jurisdiction in some EU Member States see MAARTJE DE VISSER, Constitutional Review In Europe - A Comparative AnAlysis ch. 3 (2014).

${ }^{8}$ Tom Ginsburg \& Zachary Elkins, Ancillary Powers of Constitutional Courts, 87. TEX. L REV. 1431, 1443 (2009) (curiously in the first page they also identify reviewing the compatibility of an international treaty with the constitution as part of the paradigmatic constitutional review power).

${ }^{9}$ In INTERNATIONAL LAW AND DOMESTIC LEGAL SySTEMS (Dinah Shelton ed., 2011) some country reports where constitutional review of treaties exist make no mention of it (e.g. Germany and Venezuela) or merely acknowledge its existence (Russia and Slovakia) and the editors introduction only acknowledges one form of review - ex ante treaty review - in a single sentence. In NATIONAL TREATY LAW AND PRACTICE (Duncan Hollis, Merritt Blakeslee \& Benjamin Ederington eds., 2005) some country reports also make no reference to this possibility (Japan), and others simply refer to the existence of this power (e.g. Austria, Colombia and Russia) with the editors comparative overview also making only the briefest reference to this.
} 
implications that can flow from, treaty-making. The second section advances the case for constitutional systems to adopt a combined system of ex ante and ex post constitutional review of treaties. In doing so it draws on the preceding section, most prominently the changing remit of treaty-making identified therein, while responding to several core objections that could be advanced against having constitutional review of treaties. In particular it is underscored that ex post treaty review can, contrary to conventional wisdom, be designed and practiced fully compatibly with international law obligations.

\section{Transformations relating to treaty-making \& the treaty-making power}

\subsection{Qualitative and quantitative transformations in relation to treaty-making}

Treaties have been concluded for thousands of years, ${ }^{10}$ but crucially since the $19^{\text {th }}$ century we have seen a rapidly emerging quantitative, and more importantly a related qualitative, transformation in treaty-making. On the quantitative side, while treaties were being concluded at a rate of some 20-30 treaties a year in the $1790 \mathrm{~s}$, rather similar numbers to those that had existed since 1650 , a century later this had risen nearly seven-fold to some 140-150 treaties per year, increasing to around 200 a year by the outbreak of World War I and to over 1000 treaties by the end of the $20^{\text {th }}$ Century. ${ }^{11}$ On the qualitative side, treaty-making is no longer dominated by areas such as those of war, peace, friendship, commerce, territorial cession and delimitation that characterised earlier times. Rather treaty-making has come to in effect encompass practically all areas over which national governments regulate. Whether the area be arms control, banking, communications, consumer protection, counter-terrorism, criminal law, cyberspace, data protection, environmental protection, extradition, fisheries, food standards, health, human rights, intellectual property, investment, labour standards, migration, social security, taxation, telecommunications, trade, transport, or many other areas, a dense and growing array of treaties and treaty derived law are to be found. Put simply, there has been a veritable explosion in the remit of treaty-making which is in part the gradually emerging external manifestation

\footnotetext{
${ }^{10}$ See e.g. JAN KLABBERS, InTERNATIONAL LAW 4 \& 41 (2013) (pointing to ancient Greek city states having already concluded treaties with each other).

${ }^{11}$ See Edward Keene, The Treaty-Making Revolution of the Nineteenth Century, 34 INT'L. HIST. REV. 475 (2012).
} 
of the explosion in the internal regulatory capacity of the state following the industrial revolution. We have also been witnessing, as one scholar aptly puts it, the "increasingly international regulation of subject matter which hitherto was not only within the domain of States but within the domain of the administration within the State." 12 The growing regulatory layer of international law-making raises profound questions and more generally it has become increasingly easy to think of uses to which treaty-making is put that raise considerable constitutional concerns domestically. Here it is only necessary to draw attention to a few prominent controversial examples to illustrate the point.

In the field of investment, compulsory investor-state arbitration provisions in investment treaties have existed since at least the 1960s and have proliferated at a remarkable rate in the last two decades. Such provisions empower foreign investors to seek damages from States for their regulatory output before arbitration tribunals that are arguably designed, and in practice operate, in a manner skewed heavily in favour of foreign investors. ${ }^{13}$ If this capacity to sue states before arbitral tribunals due to economic consequences resulting from domestic legislative, executive and judicial decision-making were not constitutionally problematic enough, it is exacerbated further because investment treaties usually contain "survival clauses" so that investment claims can continue to be brought for a decade or even more after a state has withdrawn from the treaty.

The sovereign debt crisis in the Eurozone has seen EU policy-makers respond not only through their standard toolkit of EU law, but also controversially via ordinary treaties. ${ }^{14}$ In particular the European Stability Mechanism (ESM) Treaty was created for bailing out Eurozone states, and the interlinked ${ }^{15}$ Fiscal Compact Treaty seeks to enshrine strict fiscal discipline via enhanced centralised European oversight and a legally enforceable balanced budget obligation. The combined constitutional ramifications of these twin treaties are profound - given the striking reduction in budgetary autonomy and the exposure to potentially considerable

\footnotetext{
${ }^{12}$ Joseph H. H. Weiler, The Geology of International Law - Governance, Democracy and Legitimacy, 64 HEIDELBERG J. INT'L. L. (ZaöRV) 547, 559 (2004).

${ }^{13}$ For a powerful critique of investment treaty arbitration see GUS VAN HARTEN, INVESTMENT TREATY ARBITRATION AND PUBLIC LAW (2007).

${ }^{14}$ See Angelos Dimopoulos, The use of international law as a tool for strengthening economic governance in the EU and its impact on EU institutional integrity, in THE CONSTITUTIONALISATION OF Eu Budgetary ConstrainTs (Maurice Adams, Pierre Larouche \& Federico Fabbrini eds., 2014).

${ }^{15}$ Access to bail out funds from the ESM is conditioned upon ratification and implementation of the Fiscal Compact.
} 
liabilities - and become all the more so for any state receiving ESM bailouts given the concomitant conditionality involved. Strikingly a comparative exploration of the Fiscal Compact concludes that while the policy rhetoric during the Euro crisis has been one of rejecting a federal arrangement, the end result is a fiscal regime for eurozone governance that sacrifices state sovereignty to a much greater degree than in a federal system such as the US. ${ }^{16}$

If we turn to the terrain of the World Trade Organisation we can think of the general controversy over the impact of trade obligations on the capacity of states to fulfil human rights obligations, ${ }^{17}$ and more specifically whether the intellectual property protection it offers impedes access to essential medicines in developing countries, ${ }^{18}$ or whether excessive constraints are imposed on sovereign regulatory choices that seek to protect health, safety and the environment. ${ }^{19}$

The WTO, like the EU, is of course an international organisation and these have been proliferating at a remarkable rate since the end of the Second World War, ${ }^{20}$ such that it is now possible to assert that "there is hardly a human activity which is not, to some extent, governed by the[ir] work". ${ }^{21}$ They have increasingly become "law-makers" 22 including via the exercise of "sovereign powers", 23 perhaps most controversially in recent times via the most powerful decision-making organ, the Security Council, of the most famous international organisation of all, the United Nations, which in the post 9/11 period has been accused of arrogating to itself a legislative role. ${ }^{24}$

In sum, it has become increasingly clear that a quantitative and qualitative transformation in international law-making via treaty has taken place and this inevitably has placed pressure on domestic constitutions to respond.

\footnotetext{
${ }^{16}$ Federico Fabbrini, The Fiscal Compact, the "Golden Rule," and the Paradox of European Federalism, 36 B.C. INT'L \& COMP. L. REV. 1, 37 (2013).

17 See Michael Trebilcock, Robert Howse \& Antonia Eliason, The Regulation OF INTERNATIONAL TRADE, ch. 18 (2013).

${ }^{18}$ See id, at 546-550.

${ }^{19}$ See id, ch. 8 \& 17.

${ }^{20}$ Alvarez points to the existence of thirty-seven in 1909 , which had risen to 132 by 1956 and 378 by 1985 albeit in decline since then: José Alvarez, InTERnATIONAL OrGANIZATIONS As LAW-MAKERS 23 (2005).

${ }^{21}$ JAN KLABBERS, AN INTRODUCTION TO INTERNATIONAL ORGANISATIONS LAW 22-23 (2015).

${ }^{22}$ A term used in a capacious fashion in an important study by Alvarez, see supra note 20.

${ }^{23}$ Terminology employed by Sarooshi whose monograph explores the exercise by international organisations of a full range of executive, legislative and judicial powers that are commonly referred to as sovereign powers when exercised by states: DAN SAROOSHI, INTERNATIONAL ORGANISATIONS AND THEIR EXERCISE OF SOVEREIGN POWERS (2005).

${ }^{24}$ See AlvarEZ, supra note 20, at 199-217.
} 


\subsection{Constitutional transformations relating to the treaty-making power}

This sub-section draws on a wide array of constitutional texts in order to identify core ways in which domestic constitutions have responded to the transformed remit of treaty-making, focussing firstly on the role accorded to parliaments and the people, and secondly the courts.

\section{a) Parliaments and the people}

The treaty-making power is traditionally an executive power par excellence. It was, like its intimate relation the war-making power, vested in the monarch. ${ }^{25}$ Historically the remit of treaty-making was of course limited indeed and included the other side of the coin to the monarch's power to declare war, namely to negotiate and conclude peace treaties. For the early exponents of separation of powers thinking, Locke and Montesquieu, this is where the treaty-making power belonged and should not be constrained by a legislative body much less exercised by it. ${ }^{26}$ Even well after the English Revolution of 1689 had secured the Westminster Parliament's central place in the law-making process, the English jurist William Blackstone was to exhibit disdain for a legislative approval role for treaties. ${ }^{27}$ As for Rousseau, his vision of direct democracy did not encompass the treaty-making power which he appeared content to leave firmly in the hands of rulers who apparently had no incentive to conclude treaties disadvantageous to the country. ${ }^{28}$

Whilst there were prior historical instances in which legislative approval for treaty-making had taken place, ${ }^{29}$ it is with the Philadelphia Convention that more meaningful consideration to the appropriate role for the legislature began. ${ }^{30}$ And having considered giving both houses some form of majority approval requirement

\footnotetext{
${ }^{25}$ For a historical discussion see Peter Haggenmacher, Some Hints on the European Origins of Legislative Participation in the Treaty-Making Function, 67 CHI.-KENT. L. REV. 313 (1991).

${ }^{26}$ For discussion of Locke and Montesquieu's views see Boris MirkinE-GUETZEVICH, DroIT CONSTITUTIONNEL INTERNATIONAL [INTERNATIONAL CONSTITUTIONAL LAW] 97-99 (1933).

${ }^{27}$ William Blackstone, COMmentaries On The Laws Of England, Book 1, ch. 7. (1766) ("who would scruple to enter into any engagements, that must afterwards be revised and ratified by a popular assembly.").

${ }^{28}$ See Jean Jacques Rousseau, Lettres Écrites De La Montagne [Letters Written From The MounTAIN], Seconde partie, Septième lettre (1764).

${ }^{29}$ For example, WILDHABER, supra note 4, at 9, notes instances of French Kings having submitted treaties to legislative approval.

${ }^{30}$ Under the Articles of Confederation (Art. IX) the treaty-making power was vested in the Congress requiring support from representatives from nine of the thirteen States: see LOUIS HENKIN, ForEIGN AfFAirs AND THE United States Constitution, 175 \& 444 (1996).
} 
and even allocating the treaty-making power to the senate, the final choice was for the treaty-making power to be accorded to the President with a requirement for senate advice and consent by a two-thirds majority. ${ }^{31}$

Two key points need to be kept in mind in relation to the emergence of this first partial legislative approval requirement for treaties. Firstly, that the Philadelphia Convention also produced the initial, and much copied since, "automatic treaty incorporation clause". That is a constitutional clause giving approved treaties automatically the status of domestically judicially enforceable law. ${ }^{32}$ And how the treaty-making power would be regulated, if at all, becomes all the more important given this enhanced domestic legal status for treaty law. Secondly, it was only a limited democratisation of the treaty-making power for the Senate itself was not initially directly elected. ${ }^{33}$ It was, in contrast to the House of Representatives, accorded a role precisely because of this, combined with its small size and thus capacity for secrecy, which would in theory allow it to operate in a fashion more akin to a privy council or council of state. ${ }^{34}$ Crucially the emergence of this very first legislative chamber approval requirement for treaties needs to be understood as a measure to protect the states in the context of the centralisation of power that the move to federation constituted.

Historically the next major step in the constitutional regulation of the treatymaking power emerged on the other side of the Atlantic with the first post-revolution constitution in France. Although not containing the bold advice requirement of the US Constitution, ${ }^{35}$ the executive's treaty-making power was constrained by the need for legislative approval and thus an intentionally greater democratisation of the treatymaking power than that created by the constituent power in the US, and one which was expressly driven by notions of popular sovereignty. This requirement from the 1791 Constitution was replicated in the Constitutions of 1793 and 1795, but a dedemocratisation of the treaty-making power took place with the Napoleon-inspired

\footnotetext{
${ }^{31}$ On the genesis of the US treaty-making power see C.H. McLaughlin, The Scope of the Treaty Power in the United States, 42 MinN. L. REV. 709, 732-739 (1958).

${ }^{32}$ Article VI, section 2 U.S. CONST. 1787 states "all treaties made...shall be the supreme law of the land".

${ }^{33}$ Members were elected by the state legislatures, it becoming wholly directly elected following the ratification of the seventeenth amendment in 1913.

${ }^{34}$ See HENKIN, supra note 30, at 443-444.

${ }^{35}$ An intended advice function that atrophied and died early, see Louis Henkin, Treaties in a Constitutional Democracy, 10 Mich. J. INT'L L. 406, 410-411 (1989).
} 
Constitution of 1802 which removed the legislative approval requirement and which was not formally reinserted until $1848 .^{36}$

The next major moment came with the Belgian Constitution of 1831, which provided for a legislative approval requirement for certain categories of treaties including crucially those that bind individuals. ${ }^{37}$ This approach of requiring parliamentary approval for certain defined categories of treaty has been widely replicated in constitutional documents ever since $1831 .^{38}$ It is also the system that France has followed since 1875 and was followed by most of France's former African colonies. ${ }^{39}$ There are two main alternative approaches. One is to have constitutional text requiring that in principle, as with the US, all treaties require parliamentary approval, ${ }^{40}$ but usually encompassing both the houses of a bicameral system. ${ }^{41}$ It is this approach that was generally followed by Latin American republics, beginning with Argentina (1853). ${ }^{42}$ The other approach, which has relatively few adherents, is essentially to not constitutionally require, subject to limited exceptions, parliamentary approval for treaties. This approach is associated with countries with a common law background, in which treaties have traditionally not been considered to be part of the law of the land, absent legislative approval, and in which such approval is infrequent. It is this formalistic reliance on the mantra of treaties not being part of the law of the land without legislative approval that has enabled these countries, which include Australia, Canada, India, New Zealand, Nigeria, and the UK, ${ }^{43}$ to resist a meaningful ${ }^{44}$ democratisation of the treaty-making power. ${ }^{45}$ Today, the vastly

\footnotetext{
${ }^{36}$ See WILDHABER, supra note 4 , at $11-12$.

${ }^{37}$ See Charles De Visscher, De La Conclusion Des Traités Internationaux: Étude De Droit CONSTITUTIONNEL COMPARÉ ET DE DROIT INTERNATIONAL [ON THE CONCLUSION OF INTERNATIONAL TREATIES: A COMPARATIVE CONSTITUTIONAL LAW AND INTERNATIONAL LAW STUDY] 42-43 (1943).

${ }^{38}$ A recent example is the Tunisian Constitution (2014, art. 67). All current constitutions cited were obtained from the Constitute website: www.constituteproject.org/

${ }^{39}$ To cite the current constitutions of a few of these countries: Algeria (1989, art. 131); Burkina Faso (1991, art. 149); Central African Republic (2013, art. 96); Djibouti (1992, art. 62); Gabon (1991, art. 114); Mauritania (1991, art. 78); Morocco (2011, art. 55); Senegal (2001, art. 96).

${ }^{40}$ Though in practice mechanisms emerge, as they first did in the US via executive agreements, to bypass this requirement. For early comparative analysis of simplified agreements, see WILDHABER, supra note 4 , at 72-74, 106-146.

${ }^{41}$ The constitutions of Cuba (1901), Mexico (1917) and Ecuador (1929) were exceptions that opted for a senate approval requirement alone: see DE VISSCHER, supra note 37, at 94

${ }^{42}$ And according to DE VISSCHER, supra note 37, at 102-103, including amongst others Bolivia (1880); Brazil (1937); Chile (1925); Colombia (1886); Costa Rica (1871); Guatemala (1879); Nicaragua (1911); Panama (1918); Paraguay (1870); Peru (1933); Uruguay (1934); Venezuela (1931).

${ }^{43} \mathrm{Of}$ this group, one has expressly articulated what is essentially the British common law position into the constitutional text: Nigeria (1999, section 12).

${ }^{44}$ The qualifier meaningful is added to encapsulate at least requiring legislative approval for some significant classes of treaty. Some of these constitutional systems have undergone changes to give
} 
overwhelming majority of constitutional systems require legislative approval of at least certain important, and often widely defined, categories of treaties. ${ }^{46}$

An additional constitutional transformation has been to permit or require more onerous procedures for certain types of treaty than merely ordinary parliamentary approval. $^{47}$ Most striking in this respect has been the emergence of the treaty approval referendum. The first key step occurred when the pioneer of direct democracy that is Switzerland amended its Constitution in 1921 to allow for certain treaties to be put to the people. The types of treaties subject to this optional treaty referendum have since been significantly expanded and an obligatory treaty referendum was added as well. ${ }^{48}$ France was the next constitutional system to expressly give a potentially prominent role to the treaty referendum by providing via its 1958 Constitution (art. 11) for its potential use in relation to treaties that impact on the functioning of the institutions. Today in numerous constitutional systems the

parliament a greater role, including a veto power for the UK House of Commons: see the comparative discussion of Australia, Canada, New Zealand and the UK in CAMPBELl MClachlan, ForeigN RELATIONS LAW 161-181 (2014).

${ }^{45}$ It is formalistic in the sense that whilst treaties may not technically be part of the law of the land they can nonetheless have significant domestic legal impacts. Thus famously the Australian High Court held that the ratification of a treaty could create a legitimate expectation that the executive would comply even though it had not been incorporated: see Minister for Immigration and Ethnic Affairs $\mathrm{v}$ Teoh (1995) 128 ALR 353. In any event treaties are internationally binding and therefore in practice constrain domestic freedom to maneuver.

${ }^{46}$ A range of examples from different parts of the world include: Angola (2010, art. 161(K)); Argentina (1853, art. 75(22) \& (24)); Austria (1920, art. 50(1)); Brazil (1988, arts. 49 \& 84); China (1982, art. 67(14)); Colombia (1991, arts. 150(16), 101 \& 224); Congo (DRC) (2005, art. 214); Croatia (1991, art. 140); Czech Republic (1993, art. 49); Ecuador (2008, art. 419); Estonia (1992, art. 121); Finland (1999, section 94); France (1958, art. 53); Georgia (1994, art. 65); Germany (1949, art. 59(2)); Greece (1975, art. 36(2)); Guatemala (1985, art. 171); Honduras (1983, arts. 16 \& 245(13)); Iceland (1944, art. 21); Indonesia (1945, art. 11); Italy (1947, art. 80); Japan (1946, arts. 73(3) \& 61); Jordan (1952, art. 33(2)); Lithuania (1992, art. 138); Norway (1814, art. 26); Poland (1997, art. 89); Portugal (1976, art. 161(i)); Romania (1991, arts. 75 \& 91); Russia (1993, art. 106); Slovakia (1992, art. 7(4)); South Africa (1996, section 231(2)); South Korea (1948, art. 60(1)); Spain (1978, section 94); Sweden (1974, ch. 10, art. 3); Switzerland (1999, art. 166); Thailand (2014, section 23); Turkey (1982, art. 90); Uruguay (1985, arts. 85(7) \& 168(20)); Venezuela (1999, arts. 154, 187(18)); Vietnam (1992, art. 70(14)). The European Parliament's approval for certain important categories of treaty is also required: Treaty on the Functioning of the European Union, art. 218(6).

${ }^{47}$ It is of course possible to constitutionally enshrine a supermajority legislative approval requirement as the ordinary treaty-making procedure, as did the U.S. Constitution (art. II). In U.S. practice however different types of treaty-making have emerged that are not "Article II treaties" requiring a supermajority in the senate, and, in modern U.S. practice, the vast majority of international treatymaking have been "executive agreements" that are not even subject to any legislative approval following conclusion much less a super-majority requirement: see Oona Hathaway, Presidential Power over International Law: Restoring the Balance, 119 YALE L.J. 140, 148-155 (2009). Aside from the US, only three other constitutional texts on the constitute website (supra note 38) expressly require super-majorities in at least one chamber as the generally stipulated treaty-making requirement: Micronesia 1981 (art. VIII, sect.4), Philippines (1987, art. XVIII: section 21) and Iraq (2005, art. 61)).

${ }^{48}$ See for details Luzius Wildhaber, Adrian Scheidegger \& Mark Schinzel, Switzerland, in NATIONAL TREATY LAW AND PRACTICE, supra note 9, at 653-656. 
treaty referendum is expressly or implicitly permitted in at least some contexts, ${ }^{49}$ and/or expressly required. ${ }^{50}$ In addition, as the referendum has increasingly become a constitutional requirement in relation to all or at least some constitutional amendments, it has also supplied a constitutional anchor for a popular vote on some significant treaties viewed as necessitating constitutional amendment. ${ }^{51}$ Treaty referendums are thus now increasingly constitutionally permissible and in some instances required. However, outside of the Swiss case, ${ }^{52}$ and referendums related to the $E U,{ }^{53}$ practice is in fact scarce.$^{54}$ It should also be noted that a bar on treaty referendums is enshrined in relatively modern constitutional texts that do otherwise employ referendums. ${ }^{55}$

Another manifestation of the more onerous procedures is the growing number of constitutional texts that enshrine increased parliamentary approval thresholds for certain treaties, ${ }^{56}$ which are nearly always a simpler route to authorising what should otherwise require a constitutional amendment. ${ }^{57}$ Such constitutional clauses are most

49 Expressly includes: Albania (1998, art. 123(3)); Bolivia (2009, art. 259(I)); Cameroon (1972, art. 36(1)(b)); Chad (1996, art. 82); Czech Republic (1993, art. 10a(2)); Ecuador (2008, arts. 104 \& 420); Latvia (1922, art. 68); Liechtenstein (1921, art. 66bis); Philippines (1987, art. XVIII); Poland (1997, art. 90(3)); Tunisia (2014, art. 82); Venezuela (1999, art. 73). Examples of implicit permission are those constitutional systems that have a broadly permissive approach to use of referendums $e$.g. for matters of national interest or some similar variant as in Algeria (1989, art. 77(10)); Benin (1990, art. 108), Burkina Faso (1991, art. 49); Iran (1979, art. 59); Mauritania (1991, art. 38); Poland (1997, art. 125); South Korea (1948, art. 72); Spain (1978, section 92); Sudan (2005, art. 217).

${ }^{50}$ Examples include: Algeria (1989, art. 131); Bolivia (2009, art. 257(II)); Burkina Faso (1991, art. 147); Croatia (1991, art. 142); Denmark (1953, section 20(2)); Egypt (2014, art. 141); France (1958, art 88(5) - now subject to a supermajority parliamentary override); Madagascar (2010, art. 137); Switzerland (1999, art. 140(1)(b)); UK (the European Union Act 2011). Some African countries require a referendum for any transfer, exchange or addition of territory: Central African Republic (2013, art. 96); Congo (2005, art. 114); Djibouti (1992, art. 62); Gabon (1991, art. 114); Mauritania (1991, art. 78).

${ }^{51}$ This was so for Ireland's accession to the EU, and Austria also used its mandatory constitutional amendment referendum procedure to accede: see Fernando MENDEZ, MARIO MENDEZ \& VASILIKI TRIGA, REFERENDUMS AND the EUROPEAN UNiON: A COMPARATIVE INQUiRy 47 \& 57 (2014). Swiss adherence to the League of Nations was subjected to a mandatory referendum in 1920 in analogy with the constitutional amendment procedure: see Wildhaber et al supra note 48, at 653 .

${ }^{52}$ Switzerland has held over one-hundred treaty referendums since formally introducing the procedure in 1921: see Wildhaber et al supra note 48, at 652-655.

${ }^{53}$ This includes referendums on accession, enlargement and EU treaty revisions: see generally MENDEZ, MENDEZ \& TRIGA, supra note 51.

${ }^{54}$ For referendum practice see the Centre for Research on Direct Democracy database at: www.c2d.ch/

${ }^{55}$ Examples include Estonia (1992, art. 106 - despite this a EU accession referendum was held); Georgia (1994, art. 74(2)); Italy (1947, art. 75); Paraguay (1992, art. 122(1)).

${ }^{56}$ For an example in relation to human rights, see Brazil (1988, art. 5(3)); state borders, see Lithuania (1992, art. 10); education, see Austria (1920, art. 14(10)); the national territory, see Honduras (1983, art. 20); the passage of foreign armed forces or temporary establishment of foreign military bases, see Guatemala (1985, art. 172).

${ }^{57}$ The parliamentary threshold itself can be higher - albeit involving less stages - than that for a constitutional amendment as in Honduras (1983, arts. 20 \& 373), the same threshold though with less stages as in Greece (1975, arts. 28(2) \& 110) and Guatemala (1985, arts. 172, \& 278-80), or 
commonly employed with respect to conferral of powers on international organisations. ${ }^{58}$ It is no coincidence that this category is mostly composed of current EU Member States given that these are precisely the states that have had to wrestle with the most profound of constitutional implications flowing from accession to, and continued membership of, a specific international organisation. ${ }^{59}$ It is however surprising that we have not seen more constitutional documents moving beyond simply including international organisations in their list of treaties needing ordinary parliamentary approval. ${ }^{60}$

The expanded parliamentary role in relation to treaty approval articulated in constitutional texts, including through increased approval thresholds, is not however to be mistaken for actual input into the content of treaty-making. The language of "advice" in the US constitution's treaty approval clause has certainly not been replicated in later constitutional texts, and indeed famously even in the US the senate advice dimension quickly became a dead letter. ${ }^{61}$ To be sure, in practice we do have constitutional systems in which the parliamentary role goes well beyond simply voting yes or no to a purely executive negotiated agreement over which they have had no previous say. The US and, increasingly, the EU are perhaps the most prominent examples of legislatures using their treaty approval powers to seek to directly shape the emerging treaty text itself. $^{62}$ But we should certainly not assume that using the

coterminous as with certain EU treaties in Germany (1949, arts. 23, 79(2)-(3)), and with human rights treaties acquiring constitutional status in Brazil (1988, arts. 5(3) \& 60(2)).

${ }^{58}$ Examples include: Croatia (1991, art. 140); Czech Republic (1993, arts. 10a \& 39); Denmark (1953, section 20); Finland (1999, section 94); Greece (1975, art. 28(2)); Latvia (1922, art. 68); Luxembourg (1868, arts. 49bis, 37(2) \& 114); Netherlands (1815, art. 92); Spain (1978, section 93); Sweden (1974, ch. 10, art. 7). In Bulgaria (1991, art. 85(1)9) and Germany (1949, arts. 23(1) \& 79) the relevant constitutional clauses are EU specific, whilst in Romania (1991, arts. 148 \& 149) they were EU and NATO accession specific.

${ }^{59}$ The first constitutional clauses authorising participation in international organisations and the sovereignty limitations that were entailed appeared in the constitutions of France (1946, section 15), Italy (1947, art. 11) and Germany (1949, art. 24(1)) and did not require more onerous approval hurdles. The supermajority hurdles first emerged with Denmark (1953, section 20) and Luxembourg (1868, art. 49bis, as amended in 1956): see Monica Claes, Constitutionalising Europe at Its Source: The "European Clauses" in the National Constitutions: Evolution and Typology, 24 Y.B. EUR. L. 81, 85 \& 91-94 (2005).

${ }^{60}$ Constitutions listing specific categories of treaty requiring ordinary parliamentary approval frequently include international organizations. Examples listed in notes 39 \& 46 include: Colombia; Djibouti; Ecuador; Estonia; France; Gabon; Georgia; Lithuania; Poland; Portugal; Senegal.

${ }^{61}$ See supra note 35.

${ }^{62}$ On Congress, see Robert Dalton, United States, in NATIONAL TREATY LAW AND PRACTICE, supra note 9, at 777-778 \& 783-84. On the European Parliament, see Ricardo Passos, The European Union's External Relations a Year after Lisbon: A First Evaluation from the European Parliament, in THE European Union's EXTERnAl RELATIONs A YeAr AfTer Lisbon 49-56 (Panos Koutrakos, ed.) (2011); Christina Eckes, How the European Parliament's participation in international relations affects the deep tissue of the EU's power structures, 12 INT'L J. OF CONST. L. 904 (2014). 
treaty approval power as a potential mechanism to shape treaty text is the norm, and it is surely no coincidence that the aforementioned examples, the US and the EU, are global economic powerhouses with two of the most powerful legislatures in the world.

There is a further way worth noting in which executives and legislatures can seek to shape not the actual treaty text itself, but rather how it applies to a given state. Treaty reservations allow states to seek (at the time of signing, ratifying or acceding to a treaty) to exclude or modify the legal effect of certain of its provisions to that state. ${ }^{63}$ This heavily executive dominated terrain has seen growth in parliamentary control, whether that be via parliamentary approval requirements for certain reservations, ${ }^{64}$ parliamentary initiation of reservations, ${ }^{65}$ or conditioning treaty approval on reservations. ${ }^{66}$ The expanded Parliamentary control has however rarely come via the express Constitutional text itself, ${ }^{67}$ as contrasted with through political practices or laws regulating treaty approval. ${ }^{68}$

One logical transformation, given the increasing role for Parliaments in treaty approval, would be to equally accord them a role in terminating treaties. The early constitutional texts expressly providing for parliamentary approval were conspicuously silent on this important constitutional question. ${ }^{69}$ Beginning in the twentieth century, however, and with increasing frequency since the latter part of the century, constitutional texts have expressly accorded the legislature a treaty denunciation approval role with at least some categories of treaties. ${ }^{70}$ However, in

\footnotetext{
${ }^{63}$ For a detailed discussion of reservations and interpretative declarations, see ANTHONY AUST, MODERn TREATY LAW AND PRACTICE ch. 8 (2013).

${ }^{64}$ See Treaty Making - Expression Of Consent By States To Be Bound By A Treaty (Council of Europe ed., 2001) (citing eleven Council of Europe states: Albania, Finland, Georgia, Iceland, Liechtenstein, Norway, Poland, Romania, Slovakia, Slovenia, Ukraine).

${ }^{65} \mathrm{Id}, 81-82$ (citing Cyprus, Luxembourg, Portugal, Sweden).

${ }^{66} I d, 82-83$ (citing Denmark \& the Netherlands). On long-established practice in the US see Dalton, supra note 62 , at $774-777$.

${ }^{67}$ Two recent exceptions are the constitutions of Chile (arts. 54(3) \& (8)) and Mexico (arts. 76(1) and $89 \mathrm{X}$ ) as amended in respectively 2005 and 2007.

${ }^{68}$ Supra note 64, at 81, citing Russia and Georgia.

${ }^{69}$ The U.S. is a classic example which has generated considerable controversy, but even very recent constitutional texts have remained silent as in the EU: on both constitutional systems see ROBERT SCHÜTZE, Foreign AFFAIRS AND THE EU CONSTITUTION 377-380 \& 399-401 (2014).

${ }^{70}$ The first country to do so appears to have been the Netherlands via its constitution as amended in 1922 (then art. 58). A selection of current examples includes: Angola (2010, art. 161(L)); Argentina (1853, arts. 75(22) \& (24) - certain human rights treaties require supermajorities for denunciation); Armenia (1995, art. 81.2); Bolivia (2009, art. 260); Bulgaria (1991, art. 85); Cape Verde (1980, arts. 190 \& 12); Central African Republic (2013, art. 96); China (1982, art. 67(14)); Denmark (1953, section 19.1); Ecuador (2008, art. 419); Estonia (1992, arts. 65(4) \& 121); Finland (1999, section 94); Georgia (1994, art. 65(1)); Lithuania (1992, art. 138); Mexico (1917, arts. 76(I) \& 89(X)); Mozambique (2004,
} 
contrast to parliamentary approval of treaty ratification, express codified constitutional text requiring parliamentary approval for denouncing at least some treaties remain rather surprisingly - in light of the significance of the issue - the minority of constitutional texts. ${ }^{71}$

\section{b) The Courts}

The final constitutional transformation to note is the emergence of constitutional review of treaties. As a matter of express constitutional design at the nation-state level, the key first step was taken when the French Constitution of 1958 introduced a system of ex ante constitutional review of treaties by the newly created constitutional council. It could be seized by certain institutional actors to assess the compatibility of a treaty with the Constitution and in the event of a negative decision the treaty could not be ratified without a constitutional amendment. A new constitutional mechanism thus emerged to reconcile the sanctity of the domestic constitutional order with the constitutionally significant ramifications that can flow from treaty commitments. Although ex ante review of treaties already emerged in the EU via the 1957 Treaty of Rome, its origins are likely to have been inspired by the discussions over introducing such a mechanism into the new French Constitution. ${ }^{72}$ Since the EU and France first expressly introduced the tool of ex ante constitutional review of treaties, its presence in constitutional texts has spread rapidly. ${ }^{73}$ We now find it especially widespread in Europe, where it originated, and in Africa and Latin America. ${ }^{74}$ As well as being an express choice in constitutional design, this ex ante

arts. 179(2)(e) \& (t)); Netherlands (1815, art. 91); Peru (1993, art. 57); Poland (1997, art. 89); Slovakia (1992, art. 86b); Spain (1978, section 96(2)); Sweden (1974, ch. 10, art. 5); Vietnam (1992, art. 70(14)). In Bolivia (2009, art. 260(III)) and Ecuador (2008, art. 420) treaties approved by referendum require termination to be subject to popular approval.

${ }^{71}$ Silent constitutional texts have been interpreted in a manner parallel to the treaty approval requirement, for Austria, see Franz Cede and Gerhard Hafner, Austria, in NATIONAL TREATY LAW AND PRACTICE, supra note 9, at 69-70.

${ }^{72}$ See ADAM, supra note 6, at 21.

${ }^{73}$ The focus here is on constitutional review by courts, including the French Constitutional Council which has long been considered to be a court in all but name not least because it can make binding rulings: see, JOHN BELL, FRENCH CONSTITUTIONAL LAW ch. 1 (1992). In some European constitutional systems - such as Belgium, the Netherlands and Luxembourg - there is non-binding ex ante treaty control performed by Councils of State. On Councils of State, see DE VISSER, supra note 7, at 13-20.

${ }^{74}$ A non-exhaustive list of European states includes: Albania (1998, art. 131(b)); Bulgaria (1991, art.149); Czech Republic (1993, art. 87(2)); Georgia (1994, art. 65(4)); Poland (1999, art. 133(2)); Portugal (1976, art. 278); Romania (1991, art. 146(b)); Russia (1993, art. 125(2)(d)); Slovenia (1991, art. 160); Slovakia (1992, art. 125a(1)); Spain (1978, section 95(2)). A non-exhaustive list of African states includes: Algeria (1989, art. 165); Angola (2010, art. 228); Benin (1990, art. 146); Burkina Faso (1991, art. 150); Cameroon (1972, art. 47(3)); Chad (1996, art. 220); Gabon (1991, art. 113); Ivory 
treaty review power has also emerged as a matter of practice in some constitutional systems as has been the case in both Germany and Ireland. ${ }^{75}$ That ex ante treaty review exists as a matter of constitutional design or practice should not however lead one to assume it is regularly used. Indeed the opposite appears to be the case and part of the explanation for this are the access constraints, it often only being the narrowest range of institutional actors that can deploy it and is even confined to heads of state alone in some systems. ${ }^{76}$

In contrast to ex ante review of treaties, constitutional texts that have expressly permitted constitutional review of treaties that have already been concluded are a rare occurrence. Austria appears to be the first country to have done so via a 1964 constitutional amendment that attributed this jurisdiction to the Constitutional Court. ${ }^{77}$ It has since been expressly provided for in Brazil, Mexico, Poland, Portugal, Serbia, and seemingly most recently also in Angola. ${ }^{78}$ There are at least as many constitutional systems in which it has emerged as a matter of constitutional practice as contrasted with express design. Examples here include Belgium, Chile, Germany, Italy, Japan, the United States and the EU. ${ }^{79}$ It might be thought that the scarcity of constitutional systems permitting it is with perfectly good reason given the particular

Coast (2000, art. 95); Madagascar (2010, art. 116(1) \& 137); Mauritania (1991, art.79); Morocco (2011, art.55); Niger (2010, arts. 120 \& 170); Senegal (2001, art. 97); Tunisia (2014, art.120). A nonexhaustive list of Latin American states includes: Bolivia (2009, art. 202(9)); Chile (1980, art. 93(3)); Colombia (1991, art.241(10)); Dominican Republic (2010, art. 185(2)); Ecuador (2008, art. 438(1)); Guatemala (1985, art. 272(e)); Venezuela (1999, art.336(5)).

${ }^{75}$ In Germany this stems from 1950's Federal Constitutional Court case-law, see Hans Rupp, Judicial Review of International Agreements: Federal Republic of Germany, 25 AM. J. CoMP. L. 286, 291 (1977). In Ireland the Supreme Court found ratification of an EU treaty revision (the Single European Act) unconstitutional (Crotty $v$ An Taoiseach [1987] 1 IR 713), a constitutional amendment duly followed prior to ratification; more recently it rejected a challenge to ratification of the ESM treaty absent a constitutional amendment: Pringle v The Government of Ireland [2012] IESC 47.

${ }^{76}$ See e.g. Angola (2010, art. 228(1)); Poland (1997, art. 133); Portugal (1976, art. 278(1)); Tunisia (2014, art. 120).

${ }^{77}$ Current art. 140a.

${ }^{78}$ Angola (2010, arts. 227 \& 230); Brazil (1988, art. 102, IIIb); Mexico (1917, art. 105(II)); Poland (1997, art. 188(1)); Portugal (1976, arts. 277, 280 \& 281); Serbia (2006, art. 167). In Spain an Organic Act $(2 / 1979)$ expressly provided for it, rather than the constitution directly.

${ }^{79}$ See on Belgium, Monica Claes, The National Courts Mandate In The European COnstitution 506-10 \& 641-5 (2006); on Chile see Troncoso Repetto, infra note 94; on Germany see Rupp, supra note 75; on Italy see ENZO CANNIZZARO, TRATTATI INTERNAZIONALI E GIUDIZIO DI COSTITUZIONALITÀ [INTERNATIONAL TREATIES AND CONSTITUTIONAL REVIEW] (1991); on Japan, see Yuji IWASAWA, INTERNATIONAL LAW HuMAN RightS AND JAPANESE LAW 100-103 (1998); on the US, see Oona Hathaway et al., The Treaty Power: Its History, Scope, and Limits, 98 CoRNELL L. REV. 239 (2013) and Curtis Bradley, International LAW In The U.S. Legal System 58-66 \& 82-83

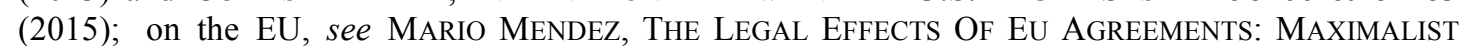
TREATY ENFORCEMENT AND Judicial AvoidAnCE TEChNiQUeS 76-93 (2013). In a number of constitutional systems, e.g., Belgium, Chile, Germany, and the EU, the treaty review takes place indirectly via review of the domestic act of approval. 
nature of treaty commitments. And, indeed, it would be precisely this kind of logic that would explain why a number of constitutional systems have as a matter of constitutional design expressly barred ex post constitutional review of treaties. ${ }^{80}$ This logic is however very much contestable as will be explained in section 3 . As concerns constitutional review of treaties by courts we are left in a situation where there are three main models in operation. Constitutional systems that

1) provide expressly or in practice for both ex ante and ex post review of treaties;

2) provide expressly or in practice for either one or other of these types of review;

3) have no possibility for either ex ante or ex post review of treaties.

The section that follows essentially advances the case for why model 1 would usually be preferable to either model 2 or 3.

\section{The case for combining ex post and ex ante review of Treaties}

\subsection{The case for ex post review of treaties}

The core argument for ex post review of treaties can be put relatively briefly. As noted in section 2.1, the remit of treaty-making has in recent times been radically transformed such that today it regulates all manner of affairs that do impact directly on individuals. And yet a treaty simply has to be consented to by the parties and "international law is agnostic on how this agreement was reached (process), who participated in its establishment (actors)...and what is actually agreed on (substance). ${ }^{\prime 81}$ It should not be surprising then that treaties can enshrine what can be viewed as constitutionally circumspect or even constitutionally egregious bargains from the perspective of the constitutional rules at play in one or more of the contracting parties. A recent and on-going controversial example in EU and US bilateral relations is the successive passenger name record treaties whereby the US gains access to passenger data from European airlines that use American airspace. As

\footnotetext{
${ }^{80}$ Examples include Luxembourg (1868, art. 95ter, para 2); Netherlands (1815, art. 120); Turkey (1982, art. 90(5)).

${ }^{81}$ Joost Pauwelyn, Ramses Wessel and Jan Wouters, When Structures Become Shackles: Stagnation and Dynamics in International Lawmaking, 25 EUR. J. INT'L. L. 733, 748 (2014). Footnote omitted. The authors note the substance point is subject to jus cogens norms.
} 
concerns their adherence to European privacy standards, all iterations of these treaties have come in for stinging criticism. As one commentator noted "[they] have justifiably been the object of severe and sustained criticism by the European Parliament, national parliaments, expert data protection bodies and civil society". ${ }^{82}$ One could certainly not envisage the EU legislature being able to adopt such lax privacy standards in an internal EU-wide PNR regime, ${ }^{83}$ and even if it did, it could always be challenged in constitutional review. ${ }^{84}$ This then is precisely a core part of the case for ex post constitutional review of treaties. For in its absence outcomes can be reached that would be unlikely to be constitutionally permissible were a purely internal rule being adopted and where in any event, given the presence of constitutional review in most constitutional systems, a constitutional challenge provides at least a potential tool for ex post verification. Indeed, one can even argue that a more compelling case for ex post review of treaties can be made than for legislation, at least as concerns well-functioning democracies. For in wellfunctioning democracies, legislation is the product of passage through a legislative procedure in which democratically elected representatives will ordinarily engage in meaningful scrutiny and deliberation, a premise central to powerful recent critiques of rights-based review of legislation. ${ }^{85}$ In contrast when it comes to the legislatures input into the treaty-making process, it is in practice largely non-existent in most constitutional systems. For where legislative approval requirements exist, and this is usually only so for at best certain and often limited categories of treaty, they generally operate in reality as little more than a formality for the executive branch to surmount with respect to treaties that are ultimately presented on a take it or leave it basis. ${ }^{86}$ Leaving it is certainly a theoretical option and could contribute to influencing the treaty content itself. But there are few, if any, constitutional systems other than the US, and perhaps now the EU, in which the parliamentary response to "leave it" would

\footnotetext{
${ }^{82}$ VAlSAMis Mitsilegas, EU CRIMINAL LAw 307 (2009). The most recent of the treaties was identified by the European Data Protection Supervisor as having key data protection shortcomings: see 2012 O.J. C 35/03.

${ }^{83}$ However, the European Data Protection Supervisor has criticised the privacy standards in the proposed internal EU wide PNR regime: 2011 O.J. C 181/02 \& 2015 O.J. C 393/09.

${ }^{84}$ Thus, for example, when the EU legislature did adopt lax privacy standards in its data retention Directive, the measure was struck down: see Joined Cases C-293/12 and C-594/12 Digital Rights Ireland, EU:C:2014:238.

${ }^{85}$ See e.g., Richard Bellamy, Political Constitutionalism (2007) and Jeremy Waldron, The Core of the Case Against Judicial Review, 115 YALE L.J. 1346 (2006).

${ }^{86}$ As concerns treaty-making SCHÜTZE, supra note 69, at 404 notes that "[w]e find the reduction of parliamentary participation to 'consent' as opposed to co-conclusion in many a state legal order."
} 
be anything other than a striking aberration. ${ }^{87}$ As such the theoretical parliamentary veto power is likely to rarely prove a meaningful constraint vis-à-vis the executive's treaty-making power. That the legislative role in treaty-making is usually marginal at best accentuates the case for constitutional review of treaties. Put simply, the salutary reach of constitutional review, which is a basic if contested tenet of modern constitutionalism, ${ }^{88}$ should extend to the product of the treaty-making process given that it applies to the product of the legislative process where parliamentarians would ordinarily have meaningful input.

Two further important points are worth noting here. Firstly, the salutary reach of constitutional review is far from exclusively about courts reviewing the product of the treaty-making process. It is crucially very much also about the executive, and to an extent the legislature, feeling obliged to ensure that constitutionalist values, including of course fundamental rights, are better respected in the treaty-making process itself. A second related point is that the deployment of such constitutionalist values can serve to bolster the legitimacy of international law by contributing to ensuring that treaty-making is more respectful of values, such as fundamental rights, central to international law. An analogy can be drawn here with the famous Kadi litigation where the European Court of Justice reviewed the domestic implementation of UN Security Council Resolutions vis-à-vis fundamental rights standards, which ultimately contributed to ensuring improved fundamental rights protection at international level. ${ }^{89}$ Eeckhout has rightly pointed out, "the due process standards which the Court applied are very similar to those of international human rights law." 90 And, in fact, ex post review of a treaty can also take place directly vis-à-vis other

\footnotetext{
${ }^{87}$ Examples of prominent treaties rejected in recent times in the US Senate include the Comprehensive Nuclear Test Ban Treaty and the UN Convention on the Rights of Persons with Disabilities, and many treaties simply languish in the Senate without a vote taking place. The European Parliament has voted against two treaties since 2010, the Terrorist Finance Tracking Program Agreement with the US, though within months it had approved a slightly amended version, and the Anti-Counterfeiting Trade Agreement: see Eckes, supra note 62. There are prominent rejections elsewhere, but these are much rarer occurrences, as was the French national assembly rejection of the European Defence Community Treaty in 1954.

${ }^{88}$ By 2011 some $83 \%$ of constitutional systems had constitutional review, up from 38\% in 1951: see Tom Ginsburg \& Mila Versteeg, Why Do Countries Adopt Constitutional Review, 30 J.L. ECON. \& ORG. 587, 587 (2014).

${ }^{89}$ See J. Kokott and C. Sobotta, The Kadi Case - Constitutional Core Values and International Law Finding the Balance, 23 EUR. J. INT'L. L. 1015 (2012). For an early critique see Gráinne de Búrca, The European Court of Justice and the International Legal Order after Kadi, 51 HARV. INT'L. L.J. 1 (2010).

${ }^{90}$ Piet Eeckhout, Eu External Relations Law 420-421 (2011).
} 
international law norms. ${ }^{91}$ Constitutional review of treaties should accordingly certainly not be thought of as a mechanism for advancing merely parochial concerns.

\subsubsection{Responding to international law, constitutional law and international relations based objections}

Having outlined the basic case for ex post review of treaties, it is essential to deal with two core interrelated strands of argument that can be advanced against such review. These can be labelled the international law objection and the constitutional law objection. The essence of the international law based objection would be to view countenancing such review as a frontal assault on international law and the central pillar of treaty law - the principle of pacta sunt servanda enshrined in Article 26 of the Vienna Convention on the Law of Treaties 1969 - and the international legal certainty it seeks to enshrine. The practical impact of this international law based objection is of considerable significance. It was, for example, this logic that was advanced to expressly exclude ex post review of treaties when Luxembourg established its constitutional court in the mid-1990s, ${ }^{92}$ and it was also logic previously relied upon by the Colombian Supreme Court to refuse ex post review of treaties. ${ }^{93}$ In Chile this rationale was also recently relied upon in justifying an organic constitutional law, which the Constitutional Court declared unconstitutional, that would have deprived it of the ex post treaty review power that it had read into the constitutional text. ${ }^{94}$ And the advisory body on constitutional matters of the Council of Europe - the Venice Commission - employed this logic recently when essentially chiding Serbia for introducing ex post treaty review into its new Constitution. ${ }^{95}$

However whether or not ex post treaty review can even generate outcomes incompatible with international law depends crucially on the model of review adopted and relatedly what, if any, consequences can flow from review. It is essential at this point to introduce the distinction between weak-form and strong-form systems of

\footnotetext{
${ }^{91}$ A very recent example is provided by the EU's General Court, infra note 108.

${ }^{92}$ See, with reference to the travaux préparatoires, Patrick Kinsch, Luxembourg, in INTERNATIONAL LAW AND DOMESTIC LEGAL SYSTEMS, supra note 9, at 404.

${ }^{93}$ Specifically rejecting review of the domestic act approving the treaty, see ALLAN BREWER-CARÍAS, JUDICIAL REVIEW IN COMPARATIVE LAW 312-313 (1989).

${ }^{94}$ For discussion see Claudio Troncoso Repetto, Control de Constitucionalidad de los Tratados. Análisis y comentarios del fallo del Tribunal Constitucional de 25 de agosto de 2009" [Constitutional review of treaties. Analysis and commentary of the Constitutional Court's ruling of $25^{\text {th }}$ of August 2009] 6 Anuario De Derechos Humanos (2010) 149-157.

${ }^{95}$ See Sanja Djajic, Serbia, in InTERNATIONAL LAW AND Domestic Legal Systems, supra note 9, at $544-546$.
} 
constitutional review. ${ }^{96}$ Put simply, under systems of weak-form review although courts do assess legislation against constitutional norms they do not have the final word on whether statutes are in compliance, whilst under strong-form review they do have the final word insofar as they are empowered to declare legislation unconstitutional and make that declaration practically effective. ${ }^{97}$ It is not necessary here to delve into the intricacies involved in extant systems of domestic constitutional review to make the basic point that one can draw on the weak-form/strong-form distinction to design models for constitutional review of treaties that operate perfectly compatibly with international law obligations. Thus one could have a system of weakform review of treaties where a court has at its disposal a non-binding declaration that a treaty is incompatible with constitutional norms. The onus can thus be shifted on to either the executive branch or the Parliament, or both, to determine whether or not to seek to renegotiate or terminate the treaty. Weak-form review where judicial challenge operates at most as a potential spur to renegotiation or treaty termination wholly consistently with international rules - a requirement which can even be expressed directly in the constitutional text - simply poses no challenge to complying with international law obligations. However, we can also design a model of strongform review of treaties - one where the judicial stance is final - which also operates entirely consistently with international law. This would be so if, for example, a constitutional system empowered courts to require the executive to seek to amend or denounce any treaty held to be unconstitutional. If such treaties continue to be fully valid internally, pending renegotiation or internationally lawful termination, there is again simply no tension with international law obligations. Essentially the same outcome can be reached as a matter of practice in a system with strong-form review, when courts can postpone the effects of their decisions as to unconstitutionality and exercise this where ex post review of treaties is conducted precisely to allow for renegotiation or internationally lawful treaty termination to take place. ${ }^{98}$ In the EU this delaying tool has been employed to allow for lawful denunciation to take place. ${ }^{99}$

There is also an argument that can be run that might allow domestic courts to deprive treaties of their internal validity in a manner that could potentially be squared

\footnotetext{
${ }^{96}$ On this distinction see MARK TUSHnEt, WEAK COURTS, Strong Rights: Judicial ReVIEW AND Social Welfare Rights In COMPARATIVE CONSTITUtional LAW chs. 2 \& 3 (2008).

${ }^{97}$ See TUSHNET, id., at ix.

${ }^{98}$ On this power in a range of constitutional systems, see BREWER-CARÍAS, supra note 7, at 94-102.

${ }^{99}$ This is not the only tool to this end that has been employed in the EU: see MENDEZ, supra note 79.
} 
with the dictates of international law. For decades prior to the 1969 Vienna Convention on the Law of Treaties (Vienna Convention), there had been much debate as to whether compliance with domestic constitutional rules conditions the international validity of treaties. ${ }^{100}$ The answer given by the Vienna Convention (Article 46) was to provide a narrow gateway by which domestic constitutional rules could be invoked to challenge the validity of treaties: states can rely on their own law as invalidating their consent to be bound where that consent was expressed in manifest violation of a provision of their internal law of fundamental importance regarding the competence to conclude treaties. There is some debate as to whether this would only permit procedural rules pertaining to the competence to conclude treaties, such as parliamentary approval requirements, or whether it would also allow substantive constitutional standards, such as fundamental rights, to be invoked. ${ }^{101}$ However, practice relating to invoking this ground of invalidity is scarce both domestically and on the international plane. It has nevertheless been argued that under the Vienna Convention domestic courts are not forbidden from deciding on the validity of a treaty. ${ }^{102}$ If this logic is correct, domestic courts could reach a conclusion as to the international validity of a treaty and deprive it of its internal legal effect without breaching international law - though this would not excuse the state itself from having to follow the Vienna Convention procedures in order to establish the treaty's invalidity as a matter of international law. ${ }^{103}$ In sum, it is crystal clear that we can design constitutional systems for ex post treaty review, whether of the weak or strong-form variety, that operate wholly compatibly with international law, ${ }^{104}$ and this may even be possible if strong-form review that can actually deprive a treaty of its internal validity is wedded to the Vienna Convention test for invalidity. It follows

\footnotetext{
${ }^{100}$ For detailed discussion see WILDHABER, supra note 4, at 146-182 \& 347-34.

${ }^{101}$ For the view that it is only procedural rules, see Michael Bothe, Article 46, in THE VIENNA Conventions on the LAW of Treaties: A Commentary 1090, 1093-1094 (Olivier Corten \& Pierre Klein eds,. 2011), for the contrary view, see Thilo Rensmann, Article 46, in VIENNA CONVENTION ON THE LAW OF TREATIES: A COMMENTARY 775, 789-90 (Oliver Dörr \& Kirsten Schmalenbach eds., 2012).

${ }^{102}$ See Benedetto Conforti \& Angelo Labella, Invalidity and Termination of Treaties: The Role of National Courts, 1 EUR. J. INT'L. L. 44 (1990).

${ }^{103}$ On these hurdles, which include giving of notice in writing to the other parties and giving them time to reply, see AUST, supra note 63, at 264-66.

${ }^{104}$ Following the Venice Commission criticism of ex post treaty review in Serbia, supra note 88, a Constitutional Court Act was adopted stipulating that treaties found unconstitutional shall cease to be effective pursuant to the provisions of the treaty and generally accepted rules of international law. This seems intended to ensure that only international law compliant outcomes can flow from ex post treaty review. Other constitutional systems where ex post treaty review exists have similar clauses e.g. Chile (1980, art. 54(5)) and Spain (1978, section 96).
} 
then that ex post treaty review should not be ruled out simply because of the inaccurate notion that its presence would generate breaches of international law.

Simply because constitutional systems can be designed to neuter the international law based objection to ex post treaty review, is not however to suggest that a case cannot be made for them to be accorded the capacity in ex post review to generate international law incompatible outcomes. One criticism of the international law compliant models based on weak-form and strong-form review suggested above that are either the spur for, or require, renegotiation or lawful treaty denunciation, is precisely that they generate scenarios in which treaties can continue to deploy their domestic legal effects despite being judicially found to, for example, constitute flagrant violations of substantive constitutional norms in a given contracting party. Lawful treaty denunciation is essentially subject to whatever the relevant treaty provides, with the parties able to agree to earlier termination, and, in the absence of a denunciation provision, it is only possible where it is established either that the parties intended to admit this possibility or where such a right can be implied by the nature of the treaty and this is subject to a minimum twelve month notice period. ${ }^{105}$ There is considerable variation in treaty withdrawal clauses, but one year denunciation rules are not uncommon and treaties can require even longer periods, or not even permit denunciation to be exercisable at all for some years. ${ }^{106}$ Accordingly, one can query whether it is appropriate to tie ex post review exclusively to international law compatible outcomes because allowing a treaty to continue to deploy domestically unconstitutional effects for potentially significant periods of time may not constitute appropriate reconciliation between the interests of constitutionalism, on the one side, and those of pacta sunt servanda and international legal certainty, on the other. Indeed, in effect, it is to concede everything to pacta sunt servanda for the only concession to constitutionalist values is wholly consistent with international law, an international law which it bears repeating is essentially, jus cogens norms aside, unconcerned with the substantive content of any bargain struck. All the more reason then why treaties should not, simply because they are treaties, be able to escape the potentially salutary reach of domestic constitutionalism by hiding behind the formal and ultimately thin veneer of legitimacy supplied by international law. The possibility to deprive a specific treaty, or at least certain of its provisions, of their domestic legal

\footnotetext{
${ }^{105}$ On the relevant Vienna Convention rules see AUST, supra note 63, ch. 16.

${ }^{106} I d$.
} 
effects and thus potentially trigger that state's international responsibility is arguably a price that can in appropriate circumstances be worth paying. It should therefore not be ruled out as a matter of constitutional design or practice in the absence of serious consideration.

It is important also not to exaggerate the potential negative repercussions that ex post review of treaties can have for international law - at least where it is not confined to weak-form review or strong-form review with international law compliant outcomes - and for international relations more generally. A range of devices in constitutional systems, to say nothing of cultural factors, constrain recourse to, and the nature of, constitutional review. Standing rules and time-limits are two obvious constraints, and there is certainly a case for applying even tighter time-limits for ex post treaty review than might otherwise apply to other norms given the implications for international relations. Thus in Belgium the general rule of six months is reduced to sixty days. ${ }^{107}$ The standard of review applied affects the nature of any constitutional review and ex post treaty review, as the terrain of foreign affairs, arguably warrants a less exacting standard of review. Indeed, in recent ex post review of treaties both the German Constitutional Court and the EU's first instance court have employed lower standards of review. ${ }^{108}$ This more fitting mechanism for recognising the specificity of international relations as compared to simply ruling out such review should not cash out in a standard of review that would appear, as in Japan, ${ }^{109}$ to empty ex post treaty review of any real meaning. Recourse to the doctrine often labelled "consistent interpretation" whereby courts strive to interpret the challenged rules compatibly with constitutional norms is also a powerful tool to minimise conflict, ${ }^{110}$ and one that has been deployed by courts in ex post treaty review. ${ }^{111}$ Indeed, the Chilean Constitutional Court has exhorted courts to make every

\footnotetext{
${ }^{107}$ See DE VISSER, supra note 7, at 113-114. Interestingly WILDHABER, supra note 4, at 374, who was no supporter of ex post review of treaties, suggested the "period should not exceed five years under almost any circumstances."

${ }^{108}$ The EU General Court ruling in Case T-512/12 Front Polisario v Council, EU:T:2015:953. On the German Constitutional Court's review of the ESM Treaty see Mattias Wendel, Judicial Restraint and the Return to Openness: The Decision of the German Federal Constitutional Court on the ESM and the Fiscal Treaty of 12 September 2012, 14 GERMAN L.J. 21 (2013).

${ }^{109}$ On which see IWASAWA, supra note 79.

${ }^{110}$ On this doctrine see ANDRÉ NOLLKAEMPER, NATIONAL COURTS AND THE INTERNATIONAL Rule OF LAW 139-165 (2011).

${ }^{111}$ For comparative discussion of Germany, Italy and the U.S., see CANNIZZARO, supra note 79, Pt I. In relation to the Brazilian Supreme Court see Eleonora Mesquita Ceia, A aplicação do princípio da interpretação conforme a Constituição no controle de constitucionalidade de tratados internacionais
} 
effort to find a conform interpretation in light of the significant international consequences for a state of holding treaty norms unconstitutional. ${ }^{112}$ In short, constitutional design and practice has a range of valuable tools at its disposal that can serve to minimise any tension between ex post review and international law and international relations.

There are also objections to ex post treaty review that can be advanced from a more explicitly constitutional law standpoint and that can be linked to the particular nature of international relations. Ultimately it remains for the executive branch to conduct the nation's foreign policy, an inherently political terrain in which treaties are a key instrument. Importance is given to the ability to conduct negotiations with if need be speed, efficiency and even secrecy. Precisely the kind of characteristics that would explain why constitutional texts continue to accord the treaty-making power expressly to the executive branch, will usually only outline limited constraints on its use, and will not expressly accord Parliament input into the actual treaty-making process itself. So whilst we have seen a radical transformation in the remit of treaty law, and its regulatory content, which makes it in this respect increasingly similar in content to ordinary domestic statute law, it remains fundamentally distinct in that it is the product of negotiations between international actors and binds the state internationally. The constitutional system that does not expressly, or as a matter of practice, provide for ex post review of treaties is simply constitutionally recognising the distinct character of foreign relations in the same way that it does so by according the treaty-making power to the executive and not to the legislature. One can, however, argue that as a matter of principle this kind of logic is inherently problematic. Indeed, its roots lie in precisely the logic advanced against any democratisation of the treaty-making power whatsoever. This perspective can be seen as a relic of a bygone era which accords an undeserved mystical quality to treaties and inappropriately allows for constitutionalism to be wholly subordinated to pacta sunt servanda and international legal certainty.

It is important to underscore that there are at least three main distinctions in terms of constitutional systems which do not have ex post review of treaties and the strength of the argument against ex post review arguably varies to some extent

[The application of the constitutional conform interpretation principle in constitutional review of international treaties]. 14 REVISTA ESPAÇO JURÍDICO 61, 79-80 (2013).

${ }^{112}$ See Troncoso Repetto, supra note 94, at 155. 
depending on which system is at stake. The system from which the strongest case against ex post review can arguably be made is one which has ex ante constitutional review of treaties. This generally modern development - at least as a matter of express constitutional design - is precisely aimed at reconciling domestic constitutionalism with the changing remit of treaty-making. It in effect constitutes some recognition of the executive empowerment that treaty-making generates and the limited meaningful input that parliamentarians can wield in this process. Ex ante review can have been chosen precisely to rule out ex post review because of the perceived negative repercussions that can flow for international law and international relations. The international law based objection has been dealt with above, namely, that it is possible to have weak-form and even strong-form review operating perfectly compatibly with international law obligations. What we can call the international relations objection is different in that one can argue that the strong-form variant of review outlined above can have negative repercussions for a state's international relations because the executive branch is being ordered to amend or bring to an end participation in a treaty that is already in force. ${ }^{113}$ Certainly terminating already extant treaty relations is, other things being equal, more likely to affect a state's relationship with its partners than would be the case with not approving a particular treaty in the first place.

There are at least two responses to this point. The first would be simply to exclude strong-form review and employ exclusively weak-form review thus neutralising the international relations objection because it can be left to the executive and/or parliament to decide whether and how to respond to a judicial ruling. The second is simply to recognise that whilst strong-form review, even in the variant wedded to lawful treaty denunciation, can indeed impact negatively on a state's international relations, this is a price worth paying to try and ensure that constitutional standards are protected. Ex ante review alone is simply not equal to this task. To be sure, other things being equal, expanding access to ex ante treaty review beyond the very narrow range of actors that can normally use it would enhance its utility. But it seems inevitable that however broad the capacity for recourse to ex ante review, some constitutionally meaningful treaties will for one reason or another manage to avoid it. A solution to that might be the alternative extreme of having compulsory ex ante

\footnotetext{
${ }^{113}$ An alternative possibility would be to bring the Constitution into line with the relevant Treaty.
} 
constitutional review as is the case in Colombia, ${ }^{114}$ but this in contrast would be to cast the net too wide given the limited constitutional significance of most treatymaking. In any event, it would not defeat the principled case for ex post review for precisely the same reasons that ex ante constitutional review of ordinary law does not defeat the core case for ex post review. The latter can allow for constitutional harms to be detected in concrete legal disputes that could go unnoticed in ex ante review particularly because of its abstract nature.

Turning now to systems that simply do not have ex post constitutional review, and thus where there is a constitutional parity in treatment afforded to both statute and treaty in this respect, a special case for why treaties should be subject to an institution that has been expressly shunned for the output stemming from the ordinary legislative process might be thought necessary. The answer here is to underscore the point made at the beginning of this section concerning the contrast between treaties and the output of the ordinary legislative process. The large and growing body of literature making powerful arguments against ex post constitutional review of legislation is generally premised on the advantages of the legislative process in functioning democracies over giving the final say on constitutional questions to unelected and unaccountable judges. Such accounts may well offer overly rosy pictures of the ordinary legislative process, but even a descriptively accurate account of the ordinary legislative process in a functioning democracy will be far removed from the reality of parliamentary input and involvement into the treaty-making process over treaties which require parliamentary approval, much less those that do not. Outlining the distinct input legitimacy from the domestic parliamentary perspective, is the core argument for having different domestic judicial treatment for treaties as compared to ordinary legislation in such constitutional systems. In addition, the core argument against constitutional review of legislation is traditionally articulated against strong-form review and, as this article has been at pains to stress, it is possible to confine treaties to weak-form review which means courts would not be given the final say over these distinct norms. This proposal of course means that such constitutional systems would have ex post review exclusively for treaties. There is, however, no reason why a constitutional system cannot accommodate this in the same way that they usually accommodate the opposite, namely, ex post review being available for domestic law

${ }^{114}$ Art. 241(10). 
but not for treaties. This is the third type of constitutional system to which we now turn.

Following the logic advanced thus far, there would be a strong case for having ex post review of treaties in constitutional systems that already have ex post review vis-à-vis domestic norms, whether or not they have ex ante review for treaties. For this is simply to extend the remit of an existing institution to a different type of norm and one that, from the standpoint of the domestic legislature, exhibits lower input legitimacy than domestic legislation. The international law and international relations based objections can be met in the same way outlined above. Implementing weakform review in a system that only has strong-form review might be thought a constitutional anomaly, but there are existing constitutional systems which combine both forms of review. ${ }^{115}$

\subsection{The case for ex ante review of treaties}

The basic case for having ex ante review in constitutional systems is that it allows for the elimination of what would be unconstitutional norms before they have even come into force. As concerns treaties specifically, part of the justification is no different from that for ex post review in so far as it flows from first acknowledging that the changing remit of treaty law makes it capable of directly impinging on constitutional values, hence the necessity for mechanisms of domestic constitutional review, which can be a means to channel values such as fundamental rights that are central to international law itself. The basic case is also premised on ex ante review being incapable of generating outcomes inconsistent with international law obligations, in contrast to ex post treaty review. This then gives rise to two main rationales for ex ante treaty review. The first would be that it is needed to ensure domestic constitutionalism can be brought to bear on treaty-making, because ex post review is viewed as impermissible, as it can lead to international law being infringed. The use of this argument to justify complete rejection of ex post review is misplaced for the reasons already articulated above, namely, that it can be exercised fully compatibly with international law. However, given the arguments advanced thus far, ex ante treaty review, whether as a matter of constitutional design or practice, is far

\footnotetext{
${ }^{115}$ In Ireland constitutional rights are enforced via strong-form review, while the ECHR has been

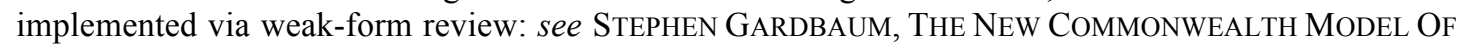
Constitutionalism 189 (2013).
} 
preferable to no constitutional review whatsoever. And the case for it is accentuated in a constitutional system where ex ante constitutional review already exists, given the anomaly of exempting treaties which are also increasingly capable of negatively impacting on domestic constitutional values, but which will in principle have been subjected to more limited domestic democratic deliberation than legislation. Where a constitutional system does not otherwise have ex ante review, a likely objection is that this is to introduce a foreign institution. The key response here is to underscore that this can be warranted precisely because of the aforementioned distinction between parliamentary input into domestic law-making and treaty-making. And, indeed, constitutional systems do exist (for example Germany, Russia and Spain) in which ex ante review is confined exclusively to treaties.

The second rationale for ex ante treaty review is that it should be viewed as an indispensable component of a more complete system of constitutional review of treaties which crucially serves to minimise, rather than eliminate, any perceived negative ramifications that flow from exclusive reliance on constitutional review of the ex post variety. Strong-form ex post treaty review - unless wedded exclusively to international law compliant outcomes as considered above - can result in outcomes that breach international law and ex ante treaty review reduces this possibility because there is at least scope for ex ante review to have already dealt with constitutionally problematic treaties. This could lead to the constitutionally problematic treaty not being concluded by the relevant state, ${ }^{116}$ or only being concluded following a constitutional amendment, ${ }^{117}$ or either changes to the treaty, ${ }^{118}$ or reservations or interpretative declarations, ${ }^{119}$ or even via a parliamentary override in the rare instance

\footnotetext{
${ }^{116}$ In France this first occurred following review of the European Charter of Regional or Minority Languages in 1999: see Gerald Neuman, The Brakes that Failed: Constitutional Restriction of International Agreements in France, 45 CORNELL INT'L L.J. 257, 326-330 (2012).

${ }^{117}$ For example, in Chile with respect to the International Criminal Court Statute, see Troncoso Repetto, supra note 94, at 152, and in France also with the ICC statute, the second optional protocol to the ICCPR and a number of EU Treaties: see Neuman, id.

${ }^{118}$ The approach in the EU following ex ante review of the first European Economic Area Agreement, see EECKHOUT, supra note 90, 232-233.

${ }^{119}$ The German constitutional court's ex ante review of the ESM Treaty called upon the government to require the treaty to be interpreted in a certain fashion and an interpretative declaration was duly agreed to by all parties prior to German ratification: see Wendel, supra note 108, at 29-31. Ex ante review in which a constitutional court requires reservations or interpretative declarations prior to ratification has been a regular occurrence in Colombia: see Ricardo Abello Galvis, La Corte Constitucional y el Derecho Internacional. Los tratados y el control previo de Constitucionalidad 1992 - 2007 [The Constitutional Court and International Law. Treaties and prior constitutional review 1992 - 2007]. ANUARIo Colombiano De Derecho InTERnACIONAL (ACDI) 263 (2008).
} 
where a constitutional order permits that. ${ }^{120}$ To be sure, some of the aforementioned outcomes that can flow from a negative ex ante ruling can have their ramifications for the state's international relations. However, this mechanism to uphold domestic constitutionalism is preferable to exclusive reliance on ex post review which is capable of not only impacting more negatively on a state's international relations, but also potentially on compliance with international law. ${ }^{121}$ And where it is not so capable because it is, for example, confined to weak-form review one can argue that this is all the more reason to have strong-form ex ante review that can reduce recourse to a form of ex post review that leaves to executive or parliamentary discretion the upholding of constitutional values.

An additional important reason for ex ante review also flows from the especially sensitive nature of constitutionally reviewing extant treaty commitments. Finding actual instances of courts holding treaties unconstitutional in ex post review is no small feat. Indeed the constitutional system in which it was first introduced as a matter of express design, Austria in 1964, still has no such instances. ${ }^{122}$ It is unsurprising to find that courts are most reluctant to do so not least as such review can take place in instances where momentous treaties have long been in force for the state concerned. A recent example is the constitutional challenge in Denmark to ratifying the Lisbon Treaty without a referendum that the Supreme Court rejected more than three years after that Treaty had entered into force. ${ }^{123}$ The additional advantage of ex ante treaty review is thus that it gives courts the possibility to conduct more probing review in less politically contentious circumstances than that of reviewing a treaty already in force for the state concerned. This is, of course, no plea for relying on ex ante treaty review alone which, as already noted above, cannot be a complete

\footnotetext{
${ }^{120}$ The Portuguese Constitution (1976, art. 279(4)) allows for a parliamentary override by a two-thirds majority of those present which must be more than an absolute majority of members.

${ }^{121}$ It is thus unsurprising that the Venice Commission called on Serbia to add ex ante review of treaties to its existing system of ex ante review, see Djajic, supra note 95. Following a recent ex post treaty review, the Austrian Constitutional Court President called for a change so that treaties could be reviewed before ratification: "Urteil: ESM-Vertrag nicht verfassungswidrig", DiePresse.com, (03.04.2013) available at: http://diepresse.com/home/politik/eu/1383770/Urteil_ESMV\%20ertragnicht-verfassungswidrig

${ }^{122}$ Whilst ex post review of EU treaties by the ECJ has regularly been successful, this has nearly always concerned the domestic approval procedure rather than the substance of the treaty: see MENDEZ, supra note 79. The EU system also allows for review of treaties concluded by its member states and successful substantive challenges have not been uncommon, with the ECJ generally requiring its member states to renegotiate or terminate such treaties: See Panos Koutrakos, Eu INTERNATIONAL RELATIONS LAW ch. 9 (2015).

${ }^{123}$ See on that case Peter Biering \& Susanne Lehrer, To Hold a Referendum or Not?, 21 EUR. PUB. L. 169 (2015).
} 
substitute for ex post treaty review, but rather should be seen as an invaluable complement to it. For this to be practically so, however, the commonly restricted access to ex ante treaty review noted above needs to be addressed. If constitutional systems continue to be designed in a manner that offers only the most limited institutional access to ex ante treaty review then its benefits can become more theoretical than real. A noteworthy example is Poland, where it can only be triggered by the head of state and has never been used, whilst, in contrast, ex post challenges can be used by a broad array of actors including parliamentarians that have brought a number of unsuccessful challenges to EU treaties as well as a pending challenge to the Fiscal Compact Treaty. ${ }^{124}$ Expanding the range of actors who can have access, ${ }^{125}$ and the conditions under which they can do so, ${ }^{126}$ is thus advisable and all the more so one might argue in constitutional systems where ex ante treaty review is restricted to a narrower range of actors, or more taxing requirements, than for ex ante review of legislation. ${ }^{127}$ Indeed it is also appropriate for constitutional design and practice to give serious consideration to the benefits of allowing individuals to bring ex ante challenges. Germany and Ireland are two rare instances in which this is possible, ${ }^{128}$ while Colombia's system of compulsory ex ante treaty review expressly allows any individual to defend or challenge their constitutionality (art. 241(10)). As far as institutional actors are concerned, it is ultimately also about a willingness in practice to exploit this constitutional resource, not least so that less pressure is placed on ex post review. ${ }^{129}$ To that end, a further choice of design or practice that is advisable is to ensure that initiation of ex ante treaty review precludes the relevant state from

\footnotetext{
${ }^{124}$ On the latest of these Constitutional Court rulings and its pending Fiscal Compact ruling, see Katarzyna Granat, Approval of Article 136 TFEU Amendment in Poland: The Perspective of the Constitutional Court on Eurozone Crisis Law, 21 EUR. PUB. L. 33 (2015).

${ }^{125}$ The opposite route was adopted in Hungary where the Parliament's power to seek ex ante treaty review was removed in 2011, see DE VISSER, supra note 7, at 104.

126 There is considerable variation in the numbers of Parliamentarians required to trigger review. At the highest end is the EU where a majority is needed, but at the nation-state level the higher end is generally one-third of Parliamentarians (e.g, Cameroon (1972, art. 47(3)); Mauritania (1991, art. 79); Slovenia (1991, art. 160)); and at the lowest end one-tenth (e.g., Burkina Faso (1991, art. 157); Niger (2010, art. 170)).

${ }^{127}$ Examples of a narrower range of actors include: Angola (2010, arts. 228(1)\&(2)); Benin (1990, arts. 121 \& 146); Portugal (1976, art. 78); Slovakia (1992, art. 130); Tunisia (2014, art. 120). An example of more stringent conditions is Ivory Coast (2000, art. 95).

${ }^{128}$ The Irish Supreme Court cases, supra note 75, were brought by individuals.

${ }^{129}$ Despite ex ante treaty review existing in Spain for close to four decades, and a comparatively low number of parliamentarians able to trigger its use, it has only generated two challenges and both were particularly momentous EU treaties (Maastricht and Lisbon).
} 
ratifying the treaty. ${ }^{130}$ For it not to have this suspensive effect only encourages greater recourse to ex post review and exposure to its potentially more challenging consequences. Thus in the EU, where the ECJ has ruled that it has no suspensive effect, ratification has occurred twice while the ex ante procedure was pending and both instances led to ex post challenges. ${ }^{131}$ Suspensive effect arguably also accentuates the importance of time-limits for ex ante treaty review rulings to be delivered given the potential implications that lengthy delays can have for the conduct of foreign relations. ${ }^{132}$ That said, the extremely tight standard time frames in some constitutional systems - as contrasted with fast-tracking in urgent scenarios ${ }^{133}$ - is only ever likely to lead to perfunctory review, and therefore to be avoided, especially if it is to exist in a system with ex post treaty review thus placing additional pressure on the latter mechanism. ${ }^{134}$

\section{Conclusion}

This article has argued that the changing remit of treaty-making warrants appropriate mechanisms of domestic constitutional review. There is little better recent illustration of the emerging constitutional controversies to which treaty-making can now give rise than the on-going debates in the EU about the impact of passenger name record treaties on European privacy standards, and the cacophony of criticism generated by the proposal to include provisions in the EU-US Trade and Transatlantic Investment Partnership that would allow the EU's Member States to be sued because of their regulatory choices before arbitration tribunals by disgruntled foreign investors. To be sure, the most widespread domestic constitutional transformation in response to the growing recognition of the significance of the treaty-making power has been requiring Parliamentary approval for at least a range of important categories of treaty. But this is inadequate compensation for the enormous power that treaty-

\footnotetext{
${ }^{130}$ Examples of constitutional design prohibiting ratification pending the ruling include the Czech Republic (1993, art. 87(2)) and Georgia (1995, art. 65(4)); an example of constitutional practice is Germany: see Rupp, supra note 75, at 291.

${ }_{132}^{131}$ See MENDEZ, supra note 79, at 81.

${ }^{132}$ Some constitutional systems with express ex ante lay down no time-limits, e.g, the Czech Republic and the EU. The ECJ has usually taken quite some time before ruling, the most recent instance took 17 months: Opinion 2/13 EU:C:2014:2454.

${ }^{133}$ In Angola (2010, art. 228(4)) it is 48 days which can be reduced "due to urgency". In Portugal (1976, art. 278(8)) the 25 days can be reduced "for reasons of emergency".

${ }^{134}$ In Cape Verde (1980, art. 301(3)) the Supreme Court has a mere ten days to rule. The Chilean Constitutional Court (1980, art. 93) also has ten days, but this can be extended for another ten days "for grave and justified reasons".
} 
making bestows upon the executive branch, particularly as parliamentary approval is in most constitutional systems little more than a formality and rarely leads to meaningful input into the treaty-making process itself. One might then have expected that as constitutional design and practice has made constitutional review an increasingly staple part of modern constitutionalism, that the output of the treatymaking power would also be reviewable. In actual fact, to the extent that modern constitution-making has expressly sought to bring constitutional review to bear on the treaty-making power, it has usually been via ex ante constitutional review, with ex post review rarely being expressly provided for, and, indeed, sometimes having been expressly prohibited in constitutional texts. This article has argued that there is a powerful case for combining both ex ante and ex post review of treaties and that this is so even for constitutional systems that do not otherwise use one or even either of these forms of constitutional review. A principal objection to ex post treaty review is that it would be, or at least can be, incompatible with international law and this has actually helped fuel exclusive recourse as a matter of constitutional design and practice to ex ante treaty review which poses no such challenge. But this principal objection is misplaced given that, as this article has emphasised, ex post treaty review can be designed and/or practiced in a manner perfectly compatible with international law. Nevertheless it is tentatively suggested that a case can also be made for allowing ex post review to reach outcomes that are incompatible with international law obligations.

By adopting and using both ex ante and ex post review of treaties, constitutional systems would contribute to ensuring that treaty-making does not escape the salutary reach of domestic constitutionalism which can be a means to channel values, notably human rights, central to international law itself. This is all the more indispensable given that international law itself, certainly as far as the rules enshrined in the Vienna Convention are concerned, continues to exhibit little concern for the process and substantive content of treaty-making. Furthermore, the existence of these forms of review could contribute to ensuring that compliance with domestic constitutional standards is taken more seriously in the treaty negotiation process. And to the extent that treaty-making that is more respectful of constitutional norms emerges, domestic constitutional review, perhaps somewhat counter-intuitively, helps bolster the legitimacy of international law itself. 
